\title{
Technocratic ideology in the dessauer's philosophy of technology
}

\author{
Aleksandr Nesterov $^{1 *}$ and Aziz Azimli ${ }^{1}$ \\ ${ }^{1}$ Samara University, 443086, Samara, Russia
}

\begin{abstract}
This article discusses the relationship between technocratic and the philosophy of technology concepts. Both of these areas of sociophilosophical thought have a significant number of parallels in their development. They grew up on the basic principles that were derived in the era of antiquity. Later on in the 19th century those concepts became more acceptable, because of the scientific and technological progress. In 20th century those approaches finally formed the philosophical discourse. There are a great number of philosophers and scientists study technocracy and philosophy of technology but in our research we make references to T.Veblen, who studied the technocracy and F.Dessauer, who was German philosopher and his area of interests was philosophy of technology. The Veblen's and Dessauer's ideas of technology development and its role in the society life are analyzed in the article. And in addition to that we analyze the role of engineers and managers in the manufacturing and administrating evolution. As for the result of the research that has been made it is necessary to say that the ideas of two scientists remain relevant for the times where technocratic concepts exist.
\end{abstract}

The 20th and 21 st centuries can be characterized as the centuries of mankind development which is linked with technological progress. This improvement leads to the socioeconomical and political changes in the world. It is not surprising that an assessment of the role and importance of technology in modern society has become relevant for many branches of knowledge, including philosophy. The philosophical discourse has a diametrically opposite attitude to technology: positive and critical assessments of technology role in society.

In the beginning of the 21 st century the important question of the engineering and technology usage and what the main role of people in the century of technologies has been raised. [2]

The integral part of philosophical discourse was made by the philosophy of technology and technocratic concept. That had become an important part of philosophy since the second half of the 20th century. Despite, the fact that two concepts (philosophy of technology and technocratic concept) are similar the list of researches of those two questions is a little different. In our article we do not undertake to create something new in the genesis of technocratic thought, but we will study philosophy of technology in terms of

\footnotetext{
* Corresponding author: aynesterow@yandex.ru
} 
ontological, epistemological or axiological component of technology, and also the social concepts. As for the Russian philosophy studies researches say that there is no boundary in technocracy and philosophy of technology, but in fact there is a boundary between those two concepts.

In our article we will take into consideration the academic studies of one of the founders of the technocratic concept, who was the American economist and sociologist Torstein Veblen (1857-1929) and the German scientist and philosopher Friedrich Dessauer (18811963). The purpose of our research is to determine the Veblen's and Dessauer's vision of the future mankind development where the technological progress will play the main role.

American economist and sociologist Torstein Veblen was one of the main people whose ideas were about technocracy and he was the first scientist who disseminated those ideas around the world. He believed that any social community is a mechanism that consists of socio-economic institutions, that is, the usual ways of social life in its connection with the physical environment [12]. T.Veblen found the contradiction between constantly obsolete social institutions and the external environment in the analysis of social development. He used in his research the Social Darwinism Methodology and believed that social life is filled with the struggle of social institutions for their survival. That methodology showed that people's lives are also subordinated to the natural selection. The economic sphere is the root of the social institutions changes: "The forces that influence the reorganization of social institutions, especially in a modern industrial society have economic nature" [3].

The growth of population, people's knowledge and the technology development lead to people's lives changes. At the same time the various social groups' mindset shifts lead to the evolution of society structure [15].

The formation of an industrial society has two stages. One stage was associated with the dominance of entrepreneurs interested in the development of production and industry. The growth of production and the business scale led to the separation of industrial equipment and resources owners from managers. Because of that the entrepreneurs were connected mostly with the finances, losing touch with the industrial processes management. There were two strategies of maintaining the favorable prices on goods, the first one was the limiting production of goods and the second one was the increasing number of outputs with lower prices. And the corporate financiers decide to choose the first strategy and at the result they got the resources misallocation.

Thus, the development of the institution of private property led to the "monetary civilization" creation. Representatives of the "idle class" gradually moved away from the problems of real production towards "wasteful consumption." [4]. The consequence of their dominance was the predominance of "absentee ownership", consisting of stocks, securities, and similar fictitious bonds, which brought huge income. Financial operations became more important than goods production and, according to T. Veblen it was the main contradiction of the capitalism era. That conflict reached its golden age in the era of monopoly domination [17].

As the example T.Veblen takes the USA modern economic system as a process of merging industrial enterprises and financial sphere organization. That system is based on two pillars - industrial experts and large financial concerns that control cash flows [13]. The economic interests of the "idle class" are conceptualized in finance, the interests of the working masses are in the boundary of production. The life and habits of working people differ from the habits of the "idle class" representatives. Activities in the field of manufacturing determine people's adaptation to the interests of collective life. People become more social and they start losing "predatory" inclinations and abilities. As the researchers say "an economic man," does not help modern society, because for such people only their utility matters and the prudence prevails in their life style" [10]. 
Further development of the production sector is inconceivable without trained personnel of experts, technologists, and engineers. At the end of the 19th century these people began to come together to solve common problems, to ensure productivity growth through technology. Their comparative paucity allows unification only in the presence of the common goal.

T. Veblen saw the main task of the class of engineers in destroying the "absentee property" that affects industry in a bad way. The development of technology and large-scale machine production will determine all future social changes. People working in such fields are interested in further technological progress and scientific discoveries [17]. Only people working in that area with the special interest will be able to establish systematical production. They also will prevent chaos and stop recourses wasting. Consequently, the technocrats' concerns are organically linked to the whole society concerns.

T.Veblen describes an ideal image of technicians as people who were brought up in the judicious spirit of the real industry. These specialists have for their motto "live and let others live", and they are the guardians of public welfare. Nevertheless, he understood that the representatives of the "idle class», having vast finances would not give the authority to representatives' of technocracy. Veblen predicted the transition of authorities from one social class to another by conflicts like "engineers strikes". Conflicts like that could paralyze the whole industrial system and could lead to that people with finances would not be able to control economic situation and then the political situation in the country. T.Veblen believed that only $1 \%$ of engineers and technicians would be needed to solve problems like those ones.

T.Veblen predicted the establishing of the Technical Experts Council by the analogy with the Soviet regime in Russia. The members of the Council supposed to be representatives' of the technocrat's professional class, such as: resource engineers, transport system and sales industry representatives'. Their functions would be implementation of the economic development plans based on the two main principles: productive efficiency and resources conservation.

The establishing of the Technical Experts Council would be the beginning of a movement towards destroying the "absentee property" and making a constructive regime under the technical specialists' guidance. However, T. Veblen realized that engineers and technicians are quite strongly integrated into modern society and they would not be able to lead a protest against the socio-economic system in the near future.

The German scientist and philosopher Friedrich Dessauer was one of the founder of the first Institute of Biophysics in Germany named after M. Planck. F.Dessauer became the director of the Institute, more than that he was the leading representative of German Engineers Association. It should be admitted that in Russian philosophy researches his academic papers poorly studied. Only few researchers used his papers for their studies in the philosophy field (Wolf, 2019; Pavlenko, 2007; Nesterov, 2016; Nesterov, 2018). F.Dessauer is popular in the Western studies countries (Skrbina, 2015; Rohkraemer, 2013; Goenner, 2003). F.Dessauer described all the ideas about technocracy in the book "Controversy over Technology" ("Streit um die Technik") in the chapters 4 and 5. Those chapters are devoted to the technology consideration in the context of various spheres of public life. He points out that technology is the most important driving force for the development of society; it is present in any form of social life and reorders the globe. Technology is an integral part of the cultural heritage of mankind, since all cultural objects are simultaneously technical objects.

F. Dessauer compares the technical and economic sphere of society life, where he sees a fundamental difference in the fact that technology begins with a single person and the economy with the market development. 
Each sphere has its own law of economy. Basically, in economics law of economy is determined by the market and profit and in technology it is determined by the teleological task to be maximum applicable. He recalls his trip to the Henry Ford factory and describes two main things that struck his attention: the first one is communication between the workers and owners and the second thing is workers opportunity to get a better position at work. Such inclusion of a person in activity leads to the fact that he is fully engaged in the work process not under fear of coercion, but because of his interest in the work process. "Attention and thoroughness, which, based on the essence of technical activity, are given to the selection, any material, tool, working process and machinery improvement should be referred to the most important element of production, to the working person. The selection of anything should be made in the interests of people. In that case people will have cognitive and control functions" [5]. Those changes lead to the fact that the society felt needs in engineers, because of that high requirement for technical specialists both in their personal characteristics and level of education was developed.

New conditions create new requirements for education where the humanitarian and natural sciences need to be united. And F.Dessauer thinks that the ideal technician who gets accustomed to work with specific discipline of a "guiding field" will not be able to work in different spheres. It happens because technicians in their profession have such distinctive qualities as reliability, which is rarely seen in other areas of society life. However, going beyond the boundaries of one's professional space, coming into contact with other spheres of society - political, economic, and legal — erodes the technician "guiding field" and leads to uncertainty. "For this reason, the technician often escapes from public life. He goes back to the subject he knows. This is a familiar situation, but it is associated with weakness, which needs to be discussed in details" [5]. And it leads to the fact that technicians join the "wrong government" where they believe that temporary success is the criteria of true success.

F. Dessauer saw opposition to that fact in upbringing and education. "Technology makes history, often forcing leaders of states to make forced moves on the politics "chessboard". For this reason, the urgent task is to educate our youth, including the younger generation of technicians. They need to have the ability to make decisions and the ability to resist against imposed injustice" [5].

T.Veblen and his studies create a great importance for the future technocratic development. He criticized the capitalism as the stage of society development, where the greed for profit was the predominant factor. T.Veblen predicted the transfer of social authorities to a new social class - technocrats. He said that in future a human-being would entry the era of cybernetics and rocket science, where everything would be computerized and automated. T.Veblen considered natural science and technology to be driving forces that change society and people. Technology breaks the boundaries between people, and unites the whole world's population. The new working class is not the destitute half-wise workers of the industrial revolution era, but these are masters of their craft, mentally and spiritually developed, who can manage and understand current processes. Technology helps workers to become more responsible and they started to be involved in production process.

There are two main principles in T. Veblen's and F. Dessauer's concepts, such as: technology is the driving force for society development and the "ideal technician" should be independent of commercial benefits and political conditions. The 21 st century would face the main problem of ethical and ethics attitude to the technological progress. It would happen because the technology would play the leading role in society development.

\section{References}


1. M.N. Volf, Philosophy of Science, The Force Changing the Face of the Earth, Review of the book «The Controversy on the Technology» by Friedrich Dessauer, 1(80), .134-153 (2019)

2. V.G. Gorokhov, The Role and Place of Philosophy of Technology and Contemporary Philosophy and its Organic Connection with Philosophy of Science, Philosophy of Science, 1, 181-199 (2011)

3. S.G. Kirdina, Institutionalism in Russia in 1930-2010s: an inversion cycle?, Journal of Institutional Studies, 7 (2), 6-37 (2015)

4. N.D. Lebedeva, Why Has the Critique of the Leisure Class Run out of Steam? Matters of Fact and Matters of Concern, Logos, 29 (1/128), .27-52 (2019)

5. F. Dessauer, "Controversy over Technology" translation by A.Yu. Nesterov (Samara University, Samara, 2017)

6. A.Yu. Nesterov, Epistemological and Ontological Problems of the Philosophy of Technology: "The Fourth KIngdom” of F. Dessauer, Design Ontology, 3(21), 377-389 (2016)

7. A.Yu. Nesterov, "Controversy over Technology" by F.Dessauer as the Basis of the Semiotic Concept of Technology, Air Trafic Control and Navigation conference almanac, 83-109 (2018)

8. A.N. Pavlenko, Friedrich Dessauer's Views on Technology, History-philosophical almanac, Technological Possibility Part III, 325-352 (2007)

9. T.M.Shishkina, Conspicuous Waste and Representativeness Heuristic, Journal of Institutional Studies, 9(4), 68-79 (2017)

10. T.Foresti, American economics at the turn of the 20(th) century: Thorstein B. Veblen, Alfred Marshall, and the methodological foundations of institutionalism, Journal of the history of economic thought, 32(4), 613-615 (2010)

11. H.Goenner, Albert Einstein and Friedrich Dessauer: Political views and political practice, Physics in perspective, 5(1), 21-66 (2003)

12. T.Lawson, Cambridge Journal of Economics, Process, Order and Stability in Veblen, 39(4), 993-1030 (2015)

13. A. Nesvetailova, R.Palan, Sabotage in the financial system: Lessons from Veblen, Business Horizons, 56(6), 723-732 (2013)

14. T. Rohkraemer, Friedrich Dessauer (1881-1963) - A Political Biography of the Biophysicist and Reichstag Deputy from Frankfurt, Historische Zeitschrift, 296(1), 232234 (2013)

15. M. Schutz, A. Rainer, J.A. Schumpeter and T.B. Veblen, On economic evolution: the dichotomy between statics and dynamics, The European Journal of the History of Economic Thought, 23(5), 718-742 (2016)

16. D.Skrbina, German Metaphysical Insights Dessauer, Juenger, Heidegger, Metaphysics of Technology, 94, 70-93 (2015)

17. T.Veblen, The Engineers and the Price System (B.W. Huebsch, New York, 1921) 